\title{
Inhaltsverzeichnis/Table of Contents
}

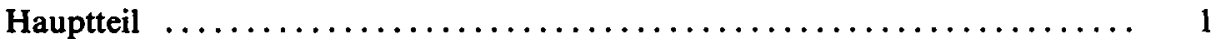

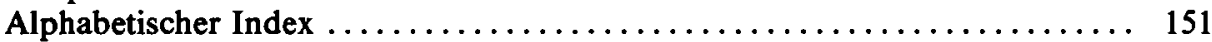

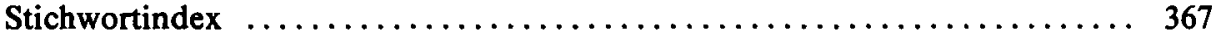

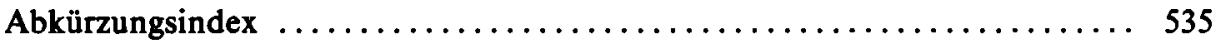

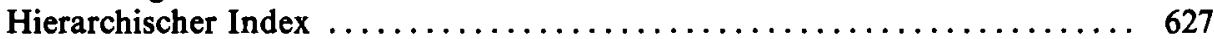

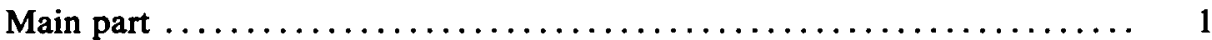

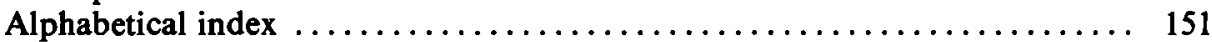

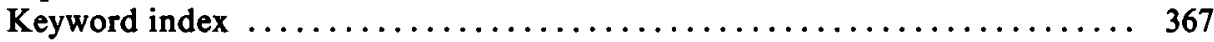

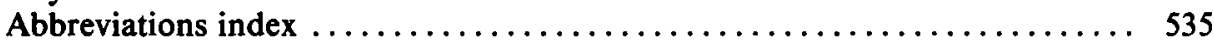

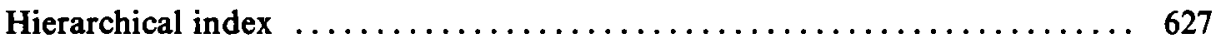

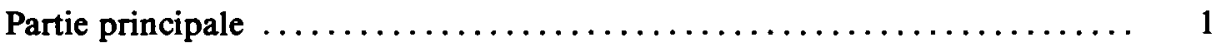

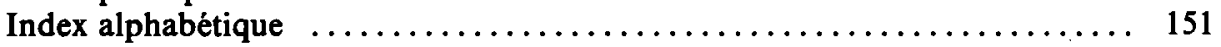

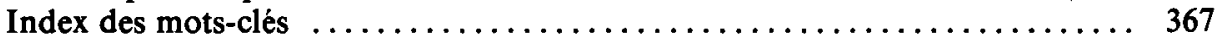

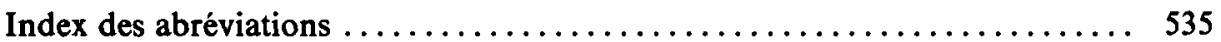

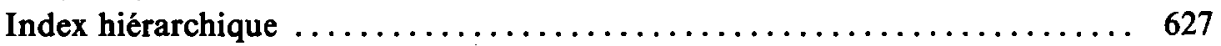

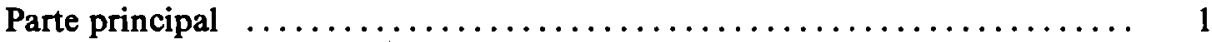

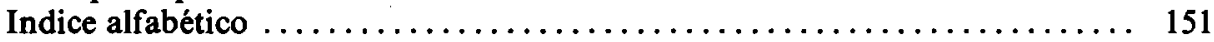

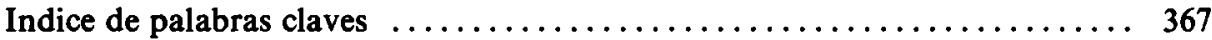

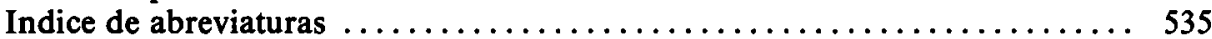

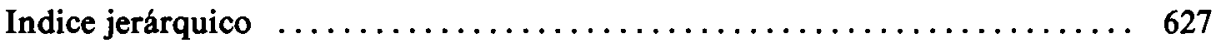

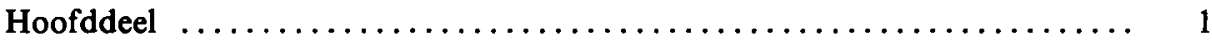

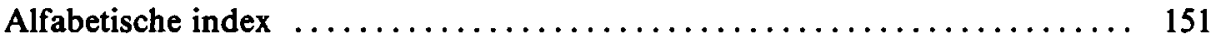

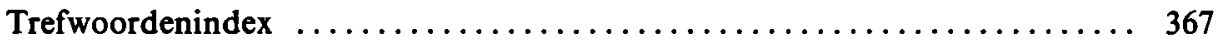

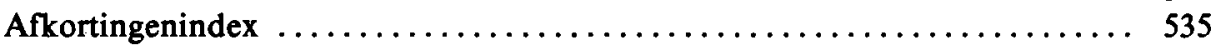

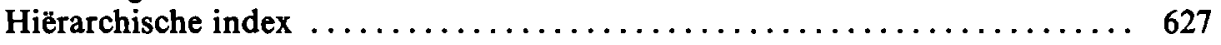

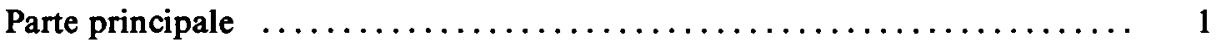

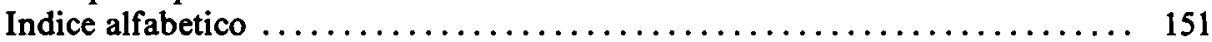

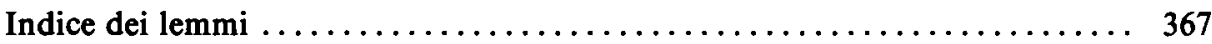

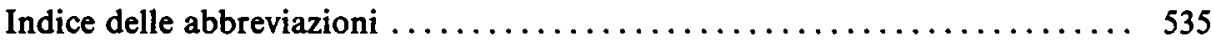

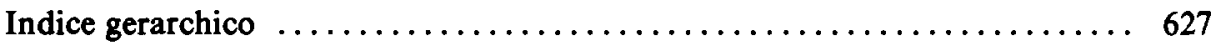

ГЛАВНЫИ РАЗДЕЛ $\ldots \ldots \ldots \ldots \ldots \ldots \ldots \ldots \ldots \ldots \ldots \ldots \ldots \ldots \ldots \ldots \ldots$

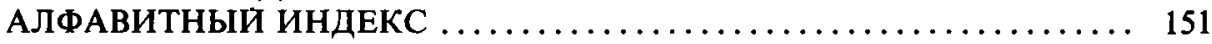

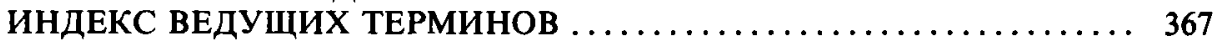

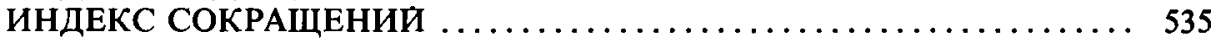

ИЕРАРХИЧЕСКИЙ ИНДЕКС ....................... 627 

Hauptteil

Main part 
